Business and Economics Research Journal
Volume 9 Number 12018
pp. $169-185$
ISSN: $1309-2448$
www.berjournal.com

\title{
Mantar Yönetim Ölçeği Geliştirilmesi Üzerine Bir Çalışma
}

\author{
Nihan Birincioğlu
}

\author{
Erol Tekin ${ }^{b}$
}

\begin{abstract}
Öz: Bu çalışmanın amacı, çalışanların mantar yönetim algılarını belirleyebilmek için bir mantar yönetim ölçeği geliştirmektir. Bu amaç çerçevesinde ölçek Açıklayıcı Faktör Analizi için 216 araştırma görevlisine (özel üniversitede çalışan), Doğrulayıc faktör Analizi için 240 araştırma görevlisine (kamu üniversitesinde çalışan) uygulanmıştır. Analizler sonucunda Kaiser-Meyer-Olkin değeri 0,874 ve Kapsam Geçerlik Indeksi 0,95 bulunmuştur. Ölçeğin açıkladığı toplam varyans oranı \% 67,238'dir. Bununla birlikte Açıklayıcı Faktör Analizi sonucuna göre ölçek 4 faktör ve 19 maddeden oluşmuştur. Bu faktörler "yetersiz bilgi paylaşımı", "güç kaybı endişesi", "yetersiz iletişim" ve "katılımcı yönetim eksikliği" şeklinde isimlendirilmiştir. Ölçeğin güvenilirliği için hesaplanan Cronbach Alpha katsayısı 0,90; test tekrar test korelasyonu ise 0,82 hesaplanmıştır. Aynı zamanda Mantar Yönetim Ölçeği DFA sonuçlarına göre iyi uyum değerlerine sahiptir. Sonuç olarak dört alt faktörden oluşan geçerli ve güvenilir bir Mantar Yönetim Ölçeği geliştirilmiştir.
\end{abstract}

Anahtar Sözcükler: Örgütsel Davranış, Mantar Yönetimi, Mantar Yönetim Ölçeği, Ölçek Geliştirme, Geçerlik ve Güvenirlik JEL Sınıflandırması: M19, D23, C80

\section{A Study on Developing The Mushroom Management Scale}

Abstract: The aim of this study is to develop a mushroom management scale and to test its validity and reliability. The scale was applied to 216 research assistant for Exploratory Factor Analysis, and 240 different research assistant for Confirmatory Factor Analysis. As a result of the analysis, the Kaiser-Meyer-Olkin value is found 0,874 and the Scope Validity Index is found 0,95. The total variance ratio explained by the scale is $67,238 \%$. In addition, according to the result of Explanatory Factor Analysis the scale consists of 4 factors and 19 items. These factors are described as "inadequate information sharing", " anxiety of power loss", "inadequate communication" and "lack of participatory management". Cronbach's Alpha Internal Consistency Coefficient is calculated 0,90 and lastly, its test-retest correlation coefficient is calculated 0,82. At the same time it can be said that according to the Confirmatory Factor Analysis the scale has satisfactory coherence criteria. As a result, a valid and reliable Mushreoom Management Scale consisting of four sub-factors is developed.

Keywords: Organizational Behavior, Mushroom Management, Mushroom Management Scale, Validity and Reliability

JEL Classification: M19, D23, C80

aAsst. Prof., PhD., Karadeniz Technical University, Business Administration Department, Trabzon, Turkiye, nihana.aydin@gmail.com (ORCID ID: 0000-0002-2707-5091)

${ }^{b}$ Asst. Prof., PhD., Kastamonu University, International Trade and Logistics Department, Kastamonu, Turkiye, etekin@kastamonu.edu.tr (ORCID: 0000-0003-1166-7671) 


\section{Giriş}

Mantar yönetim tarzına sahip yöneticiler genellikle ellerindeki gücü ve bilgiyi tek merkezde tutarak çalışanlar tarafindan sorgulanmak ve eleştirilmek istenmezler. Diğer bir ifadeyle, yöneticiler altında çalışanlara belli bir işi vermekte ancak neyi neden yapmaları gerektiğini açıklamaya intiyaç duymamaktadırlar. Bu durumda düzgün bir bilgi akışı sağlanamamakta ve bilgi asimetrisi oluşabilmektedir. Mar (2011)'a göre böyle bir ortamda yöneticiler de kararlarında kimseye fikir sormadan karar alma eğiliminde olabilmektedir. Bu tür çalışma ortamlarında çalışanların çok az bir kısmı çalıştkları kurum için yaptıkları işin ve kurumun performansının farkında olmaktadır. Bununla birlikte bu tür bir yönetim tarzı algısı çalışanların kurumdan ayrılma eğilimini artırabilir. Aynı zamanda çalışanlarda kurumlarına karşı bir güvensizlik oluşturabilir. Diğer yandan yöneticilerin, çalışanların her şeyi bilmemesinden kaynaklı olarak güçlü olduğu algısını yaratır ve bu güç zehirlenmesine neden olabilir.

Mantar yönetimin tarzından uzaklaşarak kurum içerisinde iletişim ve paylaşımı tercih etmek çalışanların kendilerini değerli hissetmelerine sebep olmaktadır. Günümüz çalışma yaşamında çalışanlar için kendilerini değerli hissetme duygusu en az maaş ve fiziksel şartlar kadar önemli olduğundan mantar yönetiminden uzaklaşmanın önemi gün geçtikçe artmaktadır. Literatürde şimdiye kadar az sayıda da olsa yapılan çalışmaların çoğunun teorik ve niteliksel olması (örneğin, Geckoboard ve Censuswide 2015; Kılıç, 2015; Tekin ve Birincioğlu, 2017) mantar yönetiminin farklı özelliklerinin açığa çıkarılmasında bir sınırlılık meydana getirmektedir. Bu nedenle mantar yönetim düzeyini ölçebilecek bir ölçek geliştirmenin literatüre katkı sağlayacağı umulmaktadır.

Bu kapsamda çalışmanın amacı eğitim camiasında gerek özel sektörde gerekse de kamuda görev yapan yöneticilerin mantar yönetim tarzı düzeylerini ölçebilen geçerli ve güvenilir "Mantar Yönetim Ölçeği" geliştirmektir. Bu amaç doğrultusunda çalışmanın bundan sonraki bölümünde mantar yönetim kavramı açıklanarak ilgili literatüre değinilmiştir. Sonrasında araştırmanın evreni ve örneklemi, veri toplama aracı, analiz yöntemi açıklanmıştır. Son olarak araştırmaya ilişkin bulgular verilerek sonuç ve öneriler ile çalışma sonlandırılmıştır.

\section{Kavramsal Çerçeve ve Literatür}

Mantar yönetimi bir metafor olarak ortaya çıkmış bir teoridir. Bu teori mantarların yetiştirilme metaforu kullanılarak yönetim bilimine yeni girmiştir. Metafora göre yönetici çalışanları mantar yetiştiriciliğinde olduğu gibi karanlıkta bırakır ve onlara sadece ihtiyacı olan kaynakları sağlayarak performansını artıracağını düşünür. Yani çalışanlara gerekli kaynaklar verilerek mantar yetiştiriciliğinde olduğu gibi gübreleme işlemi yapılmaktadır. Bunun dışında çalışanlarla bilgi paylaşımına gerek duymadan ve onlarla karşılıklı iletişim yürütmeden mantarlarda olduğu gibi çalışanın karanlıkta kalması sağlanmaktadır. Bu durumun da aynı mantarların verimindeki artı̧ gibi çalışanın performansında da bir artşa neden olacağı düşünülmektedir.

Yönetim literatürüne son zamanlarda girmiş olan mantar yönetimi, yöneticilerin çalışanları mantar yetiştirir gibi karanlıkta tutarak ve onları gübre ile besleyerek yönettiği bir yönetim tarzı olarak ifade edilmektedir. Bu teori yöneticilerin genellikle ellerindeki gücü ve bilgiyi tek merkezde tuttuklarını, çalışanlar tarafindan sorgulanmaktan hoşlanmadıklarını ve eleştirilmek istemediklerinin ifade etmektedir. Bu nedenle mantar yönetim tarzına sahip yöneticiler çalışanları ile her bilgiyi paylaşmayı tercih etmemektedirler. Diğer bir ifadeyle, mantar yönetiminin hâkim olduğu örgütlerde üstler astlarına belli bir iş vermekte ancak neyi neden yapmaları gerektiğini açıklama gereksiniminde bulunmamaktadırlar. Bu durumda düzgün bir bilgi akışı sağlanamamakta ve bilgi asimetrisi oluşmaktadır. Böyle bir ortamda yöneticiler de kararlarında kimseye fikir sonradan karar alma eğiliminde olabilmektedir (Mar, 2011). Çalışanların çok az bir kısmı kurum için yaptıkları işin ve kurumun gerçek performansının farkındadır. Dolayısıyla, mantar yönetim tarzı çerçevesinde kazankazan ilişkisinden uzak olan söz konusu üst ve astlar arasındaki ilişkinin örgüte çeşitli olumsuz etkileri görülmektedir. Bu etkilerden ilki, çalışanların kurumdan ayrılma niyetlerinin artabilme ihtimalidir. İkinci etki, çalışanların kurumlarına karşı güvensizlik duygusuna kapılmalarıdır. Üçüncü olarak, bir arada çalışan üst ve astlar arasında bilgi paylaşımının adil olmaması sebebiyle üstlerin çok daha güçlü olduğu algısının yaratılması 
ve buna bağlı olarak güç zehirlenmesi gibi durumların açığa çıkma ihtimalinin kuvvetli olmasıdır. Son olarak ise, astların çoğu kurumlarında neler olup bittiğini öğrenmek için kendi kendilerine çok fazla uğraşabilmekte, işyerinde dedikodu gibi performansı olumsuz yönde etkileyecek faaliyetlere girebilmekte ve kendilerini tam anlamıyla işlerine verememektedirler.

Mantar yönetim literatürü incelendiğinde Geckoboard ve Censuswide (2015), İngiltere'de 2000 çalışan üzerinde yapmış oldukları araştırmada çalışanların \% 50'sinin şirket bilgilerinin herkes tarafindan paylaşılması sonucunda şirket performansının artacağına olan inançlarına dikkat çekmişlerdir. Aynı zamanda araştırma sonucunda çalışanların \% 90’ının karanlıkta bırakılmaktansa (bilgisiz bırakılmaktansa) şirketin performansının kötü olmasını arzuladıkları ortaya çıkmıştır. Diğer bir ifadeyle, günümüz çalışanları çalıştıkları kurumlarda katlımcı bir yönetim tarzını tercih etmektedirler. Türkiye'de ise mantar yönetimi üzerine Kılıç (2015) dar kapsamlı sorularla sağlık çalışanları üzerine bir çalışma ortaya koymuştur. Söz konusu çalışmaya göre, yöneticilerin \% 84'ünün mantar yönetim tarzını kullandıkları, astların ise \% 87'sinin bu yönetim tarzına maruz kaldıklarını ifade ettikleri sonuçlarına ulaşılmıştır (Kılıç, 2015: 88). Tekin ve Birincioğlu (2017) ise araştirma görevlileri üzerine yapmış oldukları nitel araştırmada üniversitelerde kısmen mantar yönetim tarzının olduğu ortaya koymuşlardır. Ayrıca, mantar yönetim tarzının varlığının geleceğin akademisyenleri olarak görülen araştırma görevlilerinin performanslarını, motivasyon düzeylerini ve bağlılıklarını olumsuz etkilediği sonucuna ulaşılmıştır. Bu teorik ve nitel çalışmaların yanında Kılıç ve Olgun (2017) yaptıkları çalışmada mantar yönetim düzeyini ölçmek için tek faktörlü ve 8 ifadeden oluşan Likert tipi ölçek geliştirmişlerdir. Araştırmacılar özel bir sağlık kuruluşunda görev yapan 200 çalışana anket uygulamışlardır. Araştırma sonuçlarına göre katılımcıların \% 58'i yöneticilerin alt kademe çalışanlar ile doğrudan bir iletişim kurmadığını ve örgüte ait bazı bilgilerin paylaşmadığını ifade etmişlerdir.

Literatür incelendiğinde mantar yönetimi yeni bir kavram olmakla birlikte daha çok teorik yaklaşımlar ve nitel araştırmalarla ele alınmaktadır. Fakat literatür incelendiğinde konuya ilişkin nicel bir ölçüm aracının oluşturulması çabası da söz konusudur. Çünkü mantar yönetimi yeni araştırılan bir kavram olarak yeni yönleri ve özellikleri ortaya çıkabilecek bir konudur. Bununla birlikte bir nicel ölçüm aracının olmaması mantar yönetim tarzının diğer örgütsel davranış konuları ile birlikte ele alınmasında bir sınırlama da oluşturmakta ve kullanım alanını daraltmaktır.

\section{Araştırma Tasarımı}

Çalışmanın amacı yöneticilerin mantar yönetim tarzı düzeylerini ölçebilen geçerli ve güvenilir bir ölçek geliştirmektir. Bu amaç doğrultusunda literatür incelendiğinde mantar yönetim kavramının genellikle bilgi paylaşımından kaçınmaya, katılımcı yönetimden uzaklaşmaya, bilgi asimetrisi ve iletişim yetersizliği yaratmaya yönelik bir kavram olduğundan hareket edilerek çalışma dizayn edilmiştir.

\subsection{Evren ve Örneklem}

Çalışmanın evrenini Türkiye'deki devlet ve özel üniversitelerde görev yapan araştırma görevlisi statüsünde istihdam edilen öğretim elemanları oluşturmaktadır. Üniversiteler bilgi üreten ve bilgiyi paylaşan kurumlardır. Bu paylaşım özellikle öğretim üyeleri arasında olması gerekmektedir. İdari birimler genellikle belli kurallar ve kanunlar çerçevesinde hareket ederken öğretim üyeleri daha esnek çalışma koşullarına sahiptirler. Bu nedenle bu kurumlarda çalışan kişiler bilgi paylaşımının yeterli olup olmadığı, iletişim mekanizmalarının güçlü bir şekilde işleyip işlemediği konusunda bilgi alınabilecek kişiler olarak düşünülebilir. Ayrıca idari personelin belli çalışma kalıpları ve standartlarının olması böyle bir ölçeğin idari personeller üzerinde uygulanmasını sakıncalı hale getirebilir. Tüm bunların yanında üniversitelerde yönetici pozisyonunda bulunan kişilerin astları olarak ifade edilebilecek tek kadronun araştırma görevlileri olduğunu söylemek yanlış olmayacaktır. Bu nedenlerden dolayı çalışmanın evrenini araştırma görevlileri oluşturmaktadır.

Çokluk vd. (2012) faktör analizinde örneklem büyüklüğüne ilişkin 100=Zayıf, 200=Yeterli, 300=iyi, $500=$ Çok İyi, 1000 ve üzeri mükemmel olarak ifade etmişlerdir. Ayrıca literatürde bazı çalışmalarda madde sayısının 4 ya da 5 katı (örneğin, Child, 2006; Tabachnick ve Fidell, 2001; Özcan ve Balyer, 2013) kadar 
örneklem büyüklüğünün yeterli olduğunu savunken, bazı çalışmalarda en az 5 katı olmak üzere 7 ila 10 katı arasında (örneğin, Floyd ve Widaman, 1995; Tavşancıl, 2010) olması gerektiği ifade edilmiştir. Çalışmada verileri tam ve eksiksiz elde edilen 456 araştırma görevlisi çalışmanın örneklemini oluşturmaktadır. Elde edilen verilerden 216 tanesi Açıklayıcı Faktör Analizi (AFA), 240 tanesi ise Doğrulayıcı Faktör Analizi (DFA) için elde edilmiştir. Çalışmanın örneklem büyüklüğünün AFA ve DFA için madde sayısının yaklaşık 10 kat olduğu görülmektedir. Bu nedenle çalışmanın örneklem büyüklüğü "iyi” olarak ifade edilebilir.

Örneklemi oluşturan kişilerden 216 tanesi özel üniversitelerde, 240 tanesi ise devlet üniversitelerinde görev yapmaktadır. Ölçek geliştirme çalışması 2 grup üzerinde gerçekleştirildiğinden dolayı birinci grup özel üniversitede görev yapan 216 kişiden oluşmuştur. Bu kişilerin \% 47,2'si kadın \% 52,8'i erkektir. Hizmet sürelerine göre dağılımına bakıldığında ise 57 kişi (\% 26,4) 1-3 yıl, 131 kişi (\% 60,6) 4-6 yıl ve 28 kişi (\% 13,0) 6 yıldan daha fazla süredir kurumlarında çalışmaktadır. íkinci grup ise devlet üniversitesinde görev yapan 240 kişiden oluşmuştur. Söz konusu 240 kişinin \% 44,6'sı kadın \% 55,4'ü erkektir. Aynı zamanda 79 kişi $(\%$ 32,9) 13 yıl, 95 kişi (\% 39,6) 4-6 yıl ve 66 kişi $(\%$ 27,5) 6 yıldan daha fazla süredir kurumlarında çalışmaktadır. Birinci grupta yer alanlara Açıklayıcı Faktör Analizi (AFA), ikinci grupta yer alanlara ise Doğrulayıcı Faktör Analizi (DFA) yapılmıştır. Kişiler örnekleme alınırken şu kriterlere dikkat edilmiştir;

- Araştırma görevlilerinin kurumlarında 1 yıl ve daha fazla zamandır çalışması,

- Araşttrma görevlilerinin geçici görevli (35. Madde / 39. Madde gibi) olmaması,

- Araştırmaya katılmayı kabul etmesi.

\subsection{Veri Toplama Aracı ve Verilerin Toplanması}

Çalışma verilerinin toplanması için araştırmacılar tarafindan geliştirilen Mantar Yönetim Ölçeği (MYÖ) kullanılmıştır. Ölçeğin hazırlanması esnasında öncelikle literatür taranmış ve mantar yönetimi ile ilgili sınırlı sayıda çalışma derinlemesine incelenmiştir. Yapılan incelemelerde mantar yönetim tarzına sahip yöneticilerin tek taraflı bir iletişim kanalını benimsediği, çalışana gerekli alet edevatı sağladıktan sonra daha fazla bilgi verilmesinin gerekmediğinin savunduğu, gücü elinde bulundurmak istediği, çalışanlarla birlikte kararlar almayı doğru bulmadığı sonucuna varılmıştır. Bu kapsamda mantar yönetiminin yetersiz bilgi paylaşımı ve asimetrik bilgi problemlerini oluşturduğu, yetersiz iletişime neden olduğu ve buna bağlı olarak katlımcı bir yönetim tarzından uzak bir yaklaşım olduğu düşünülmüştür. Bu görüşler altında literatür taraması sonucunda bu ifadeleri yansıtan 24 maddelik soru havuzu oluşturulmuştur. Ölçek 5'li Likert tazında hazırlanmış ve ifadelere ilişkin cevaplar; (5) Tamamen Katılıyorum; (4) Katlıyorum; (3) Kısmen Kathlıyorum; (2) Katılmıyorum; (1) Hiç Katılmıyorum şeklinde istenmiştir.

Veriler toplanırken Mantar Yönetim Ölçeğine ilişkin anketler araştırmacılar tarafindan Açıklayıcı Faktör Analizi ve Doğrulayıcı Faktör Analizi için ayrı ayrı olmak üzere e-mail, yüz yüze görüşme ve sosyal medya hesapları aracılı̆ı ile dağıtııış ve toplanmıştır. Anketlerin dağıtımı ve toplanması Açıklayıcı Faktör Analizi için 15 Mayıs-31 Haziran 2017, Doğrulayıcı Faktör Analizi için ise 1 Temmuz-15 Ağustos 2017 tarihlerinde gerçekleştirilmiştir. Analizler için SPSS ve AMOS programlarından yararlanılmıştır.

\subsection{Verilerin Analizi}

Verilerin analiz edilirken kapsam geçerliği, yüzey geçerliği ve yapı geçerliğine bakılmıştır. Bununla birlikte güvenirlik için Cronbach Alpha ve test tekrar test yöntemleri kullanılmıştır. Ölçekteki ifadelerin ölçülmek istenen alanı temsil gücünü tespit etmek için Kapsam Geçerlik İndeksi (KGi) hesaplanmıştır. Ölçekteki ifadelerin yapıya uygunluğunu belirlemek için mantıksal geçerlik olarak da adlandırılan yüzey geçerliği yapılmıştır. Ölçeğin yapı geçerliği için ise Açıklayıcı Faktör Analizi gerçekleştirilmiştir. Ardından ortaya çıkan yapının doğruluğunu test etmek için ise Doğrulayıcı Faktör Analizleri kullanılmıştır. Faktör analizlerine ek olarak ölçeğin iç tutarlılığı hakkında bilgi elde edebilmek adına Cronbach Alfa güvenirlik değeri ve test tekrar test korelasyon değeri hesaplanmıştir. 


\section{Bulgular}

\subsection{Kapsam Geçerliği}

Kapsam geçerlik çalışması yapılırken en çok kullanılan yöntemler Lawshe (1975) ve Davis (1992)'in yöntemleridir. Lawshe tekniği hem literatürde en çok kullanılan hem de kapsam geçerlik oranlarını hesaplayan bir tekniktir. Lawshe tekniği alt aşamadan oluşmaktadır. Illk aşama geliştirilecek ölçekle ilgili alan uzmanları grubu oluşturulmasıdır. Bu aşamada yeterli bilgiye sahip ve çalışmanın önemini bilen en az 5 en fazla 40 uzman seçilmektedir. İkinci aşamada uzman görüşlerinin alınacağı formlar hazırlanmaktadır. Bu formlarda her bir madde için uzman görüşleri "madde gerekli", "madde yararlı fakat yetersiz", "madde gereksiz" şeklinde sınıflandırılır. Üçüncü aşamada uzman görüşleri değerlendirilmektedir. Bu aşamada ise her bir maddeye ilişkin uzmanlar tarafindan belirtilen görüşler tek bir formda birleştirilerek verilen tüm cevaplar toplanmaktadır. Dördüncü aşamaya gelindiğinde her maddeye ilişkin Kapsam Geçerlik Oranları (KGO) hesaplanmaktadır. KGO hesaplanırken her madde için "gerekli" cevabını vermiş olan uzmanların sayısı toplanmakta ve toplam uzman sayısına oranının bir eksiği alınarak KGO bulunmaktadır. KGO'ların bulunmasına ilişkin geliştirilen formül aşağıda görüldüğü gibidir;

$$
K G O=\frac{N_{G}}{N / 2}-1
$$

KGO: Kapsam Geçerlik Oranı NG: Uzman Sayısı (Gerekli Diyen) N: Uzman Sayısı (Toplam)

Söz konusu formüle göre ilgili maddeye uzmanların yarısı "gerekli" dediğinde KGO=0; uzmanların yarıdan daha azı "gerekli" görüşü bildirir ise $\mathrm{KGO}<0$; uzmanlardan yarıdan fazlası "gerekli" cevabını verdiğinde KGO>0 çıkmaktadır. Eğer KGO>0 çıkmayan maddeler olur ise ilk olarak bu maddeler ölçekten elemine edilmektedir. Beşinci aşamada ise Kapsam Geçerlik Ölçütlerine (KGÖ) bakılmaktadır. Standart normal dağılım ilkelerine göre hesaplanan KGÖ, her bir maddenin istatistiksel olarak anlamlı olup olmadığının testi için geliştirilmiştir. Bu noktada Veneziano ve Hooper (1997) KGÖ'lerın minimum değerlerini tabloya dönüştürmüşlerdir. Bu bağlamda Tablo 1'de $p=0,05$ anlamlılık düzeyinde KGÖ'ler görülebilmektedir. Altnncı ve son aşamada ise kapsam geçerlik indeksleri (KGi) hesaplanarak ölçeğin kapsam geçerliği test edilmiş olmaktadır. Bu aşamada her bir maddenin KGO'ları bulunduktan sonra KGÖ ile karşılaştırılarak "gerekli" olarak tespit edilen maddeler üzerinden ele alınacak olan tüm KGO'ların ortalaması alınarak KGi elde edilmektedir. Burada ölçülmek istenen özelliğin birden fazla boyutta olması durumunda her boyut için ayrı ayrı KGi elde edilmesi gerekliliği önem arz etmektedir.

Tablo 1. Lawshe Tekniğine Göre Minimum KGÖ’ler

\begin{tabular}{cccc}
\hline Uzman Sayısı & Minimum Değer & Uzman Sayısı & Minimum Değer \\
\hline 5 & 0,99 & 13 & 0,54 \\
6 & 0,99 & 14 & 0,51 \\
7 & 0,99 & 15 & 0,49 \\
8 & 0,78 & 20 & 0,42 \\
9 & 0,75 & 25 & 0,37 \\
10 & $\mathbf{0 , 6 2}$ & 30 & 0,33 \\
11 & 0,59 & 35 & 0,31 \\
12 & 0,56 & $40+$ & 0,29 \\
\hline
\end{tabular}

Çalışma kapsamında hazırlanan ölçeğin kapsam geçerliği için alandan 10 öğretim üyesinin uzman görüşleri alınmıştır. Uzmanlar için oluşturulan soru formu "gerekli", "yararlı fakat yetersiz" ve "gereksiz" olarak sınıflandırımıştır. Uzmanların maddelere ilişkin "gerekli" görüşleri dikkate alınarak KGO'lar hesaplanmıştır. Ardından çalışmada belirlenen 25 maddenin 1 tanesinin KGO'su negatif ya da sıfir çıktı̆ı̆ndan 
dolayı ilk başta ölçekten elenmiştir. Kalan maddelerin KGi'leri hesaplanmış ve KGi>KGÖ çıktı̆ından $(0,95)$ dolayı madde ve ölçeğin kapsam geçerliği kabul edilebilir düzeyde olduğu bulunmuştur. KGO'lar için uzman görüşleri alınırken ölçeğin kavramsal çerçevesine ilişkin bilgiler sunularak fikirleri alınmıştır. Bu kapsamda ölçekte iletişim problemlerinin, yönetim tarzını, bilgi paylaşım problemlerini, bilgi asimetrisini ifade eden faktör isimlerinin kullanılabileceği önerilmiştir. Faktörler dağıldıktan sonra faktör isimlerinin oluşturulmasında literatürle benzer olacak şekilde uzmanların bu görüşleri de dikkate alınmıştır. KGO'lara ilişkin bulgular Tablo 2' de özetlenmiştir.

Tablo 2. Maddelere ilişkin Uzman Görüşleri, KGO ve KGi Değerleri

\begin{tabular}{|c|c|c|c|c|}
\hline Madde & 1 & 2 & 3 & KGO \\
\hline Üstüm (yöneticim) kurumla ilgili stratejik bilgileri benimle paylaşmaktan kaçınır. & 10 & - & - & 1 \\
\hline Üstüm (yöneticim) benimle ilgili bir karar alınacağında benimle bilgi paylaşmaz. & 9 & 1 & - & 80 \\
\hline Üstüm (yöneticim) bazı bilgilerin gizli kalması gerektiğini düşünür. & 10 & - & - & 1 \\
\hline Üstlerimle (yöneticilerimle) düzenli toplantılar yaparız. (R) & 10 & - & - & 1 \\
\hline Üstüm (yöneticim) bana çeşitli yetki ve sorumluluklarını devreder. & 10 & - & - & 1 \\
\hline Üstüm (yöneticim) beni her türlü konuda bilgilendirir. (R) & 10 & - & - & 1 \\
\hline Üstüm (yöneticim) benimle bilgi paylaşımını zaman kaybı olarak görür. & 10 & - & - & 1 \\
\hline Üstüm (yöneticim) sahip olduğu bilgileri kendisi için bir güç kaynağı olarak görür. & 10 & - & - & 1 \\
\hline Üstüm (yöneticim) bizlere karşı korku kültürü yaymaya çalışır. & 10 & - & - & 1 \\
\hline Üstüm (yöneticim) kurumda yaptığım iş ile ilgili başarı elde ettiğimde bunu takdir eder. (R) & 9 & 1 & - & ,80 \\
\hline Üstüm (yöneticim) kariyerimde yükselme konusunda beni destekler. (R) & 10 & - & - & 1 \\
\hline Üstüm (yöneticim) kendimi geliştirmem için gerekli imkânları bana sunmaktan kaçınır. & 9 & - & 1 & .80 \\
\hline Üstüme (yöneticime) işlerle ilgili gerek duyduğum her an ulaşmam mümkündür. (R) & 10 & - & - & 1 \\
\hline Üstüm (yöneticim) tek taraflı bir iletişim sürecini benimser. & 10 & - & - & 1 \\
\hline Üstüm (yöneticim) yaptığım işlerle ilgili benden düzenli rapor ister. (R) & 10 & - & - & 1 \\
\hline Üstüm (yöneticim) bana ulaşırken tek bir iletişim kanalını kullanır. & 9 & 1 & - & ,80 \\
\hline Üstüm (yöneticim) herhangi bir karar alınacağı zaman benim görüşlerimi önemsemez. & 10 & - & - & 1 \\
\hline Üstler (yöneticiler) tarafından verilen talimatları (görevler) sorgulamam istenmez. & 10 & - & - & 1 \\
\hline Üstüm (yöneticim) bana çeşitli yetki ve sorumluluklarını devretmekten kaçınır. & 9 & - & 1 & 80 \\
\hline Üstümün (yöneticimin) katılımcı yönetim tarzının benimsendiğine inanmıyorum. & 9 & 1 & - & ,80 \\
\hline Üstüm (yöneticim) yeniliklere açıktır. & 10 & - & - & 1 \\
\hline Üstüm (yöneticim) şeffaflığa önem verir. & 10 & - & - & 1 \\
\hline Üstüm (yöneticim) benim iletişim bilgilerime sahiptir. & 10 & - & - & 1 \\
\hline Nihai kararlar üstler (yöneticiler) tarafından alınır. & 10 & - & - & 1 \\
\hline Uzman Sayısı & \multicolumn{4}{|c|}{10} \\
\hline Kapsam Geçerlik Ölçütü & \multicolumn{4}{|c|}{0,62} \\
\hline Kapsam Geçerlik İndeksi & \multicolumn{4}{|c|}{0,95} \\
\hline
\end{tabular}

Not= 1: Gerekli; 2: Yararlı / Yetersiz; 3: Gereksiz

\subsection{Yüzey Geçerliği}

Yüzey geçerliği bir anlamda ölçekte yer alan maddelerin Türkçeye uygunluğu, anlaşılırlığı gibi dil bilgisi kuralları açısından değerlendirilerek bu konuda pilot çalışmanın uygulanmasını ifade etmektedir. Ölçeğin yüzey geçerliğine bakılırken, ilk aşamada tüm maddelere yönelik uzman görüşleri dikkate alınmaktadır. Bu aşamada araştırmacı(lar) ölçekteki maddeleri anlaşılır ve düzgün ifade edilebilmesi açısından değerlendirerek gerekli düzenlemeyi yapmaktadırlar. İkinci aşamada çalışma evreni dışında benzer özelliklere sahip başka bir örneklem grubu tarafindan ölçeğe ilişkin maddeler anlaşılırlık, anlamlılık, okunurluk, cümlelerin doğruluk ve uzunluğu, açıklık gibi yönlerden değerlendirilmektedir. Ardından ölçeğe uygun olarak kategori sayısı (4'lü, $5^{\prime} l i$, $6^{\prime} l ı, 7^{\prime}$ li gibi) belirlenmekte ve ölçek örnekleme uygun olarak hazırlanmaktadır. Söz konusu pilot çalışmayla 
birlikte ölçekteki maddelerin örneklemin eğitim düzeyine, kültürel yapısına ve yetenek düzeyine uygunluğu da incelenmiş olmaktadır (Çam ve Arabacı, 2010: 65).

Çalışmada yüzey geçerliği için örneklemde yer almayan 30 adet araştırma görevlisine ölçekte yer alan maddelerle pilot çalışma gerçekleştirilmiştir. Çalışma kapsamında bazı ifadelerde sadeleştirmeler bazılarında ise düzeltmeler yapılarak Türkçe ve dil bilgisi kuralları açısından gerekli düzenlemeler yapılmıştır. Aynı zamanda yüzey geçerliği benzer bir örneklem grubu üzerinde yapıldığından dolayı maddelerin hem anlaşılırlık, açıklık ve anlamlılık durumları hem de ölçeğin uygulanacağı gruba uygunluğunun tespiti sağlanmıştır.

\subsection{Yapı Geçerliği}

Ölçeğin yapı geçerliğinin testi için Açıklayıcı Faktör Analizi ve Doğrulayıcı Faktör Analizi'nden yararlanılmıştır.

\subsubsection{Açıklayıcı Faktör Analizi (AFA)}

Literatürde çalışılan konuya ilişkin bir ölçeğin kaç faktör altında gruplandırıldığının bilinmediği durumlarda AFA uygulanmaktadır. Çünkü bu analiz birbiriyle ilişkisi olan birçok değişkenden daha az sayıda anlamlı yeni faktörler/boyutlar oluşturmayı amaçlayan istatistiksel bir tekniktir (Büyüköztürk, 2010). Bu nedenle öncelikle çalışmada ölçeğe ilişkin maddelerin hangi faktörlerin altında toplandığını görmek için AFA yapılmıştır (Şencan, 2005). Açıklayıcı Faktör Analizinin örneklemini farklı (özel üniversitelerinde görev yapan) 216 araştırma görevlisi oluşturmaktadır.

AFA analizinden önce ölçeğin faktör analizi için uygunluk durumunun belirlemesi amacıyla KMO ve Bartlett Testleri yapılmıştır. Sharma (1996: 116)'ya göre KMO değeri 0,90 mükemmel; 0,80 çok iyi; 0,70 iyi; 0,60 orta; 0,50 arasında ve 0,50 alt kabul edilemez olarak ifade edilmiştir. Bu nedenle KMO test değerinin 0,50 üzeri ve Bartlett Test sonucu istatistiksel açıdan anlamlı olmalıdır (Büyüköztürk, 2010; Jeong, 2004; Field, 2000). Çalışma kapsamında KMO ve Bartlett Test sonuçları Tablo 3'te özetlenmiştir.

Tablo 3. KMO ve Bartlett's Test Değerleri

\begin{tabular}{lll}
\hline KMO Testi & & $\mathbf{0 , 8 7 4}$ \\
& Chi Square & 2212.984 \\
Bartlett's Testi & Df & 171 \\
& P & 0,000 \\
\hline
\end{tabular}

Tablo 3'e göre hesaplanan KMO değeri; 0,874 olarak bulunmuştur. Bu değer 0,50'den büyüktür ve mükemmel olarak ifade edilebilir. Ayrıca Bartlett Test sonucu (Ki-Kare: 2212,984; df: 171; $p<0,05$ ) anlamlı bulunmuştur. Bulunan sonuçlar veri setinin faktör analizi için uygun olduğunu göstermektedir. Böylece ölçeğe faktör analizinin uygulanabileceği sonucuna ulaşılmıştır. Ardından MYÖ’nin yapı geçerliği ve faktör sayısını belirlemek amacıyla Varimax rotasyonu uygulanmıştr. Faktör yüklerinin alt limiti 0,40 olarak belirlenmiştir. Faktör sayısını belirlemek için birçok yöntem vardır (Dunteman, 1989: 16). Bu yöntemler öz değer istatistiği, Scree test (çizgi grafiği), toplam varyansın yüzdesi yöntemi, açıklanan varyans kriteri ve faktör sayısının araştırmacı tarafindan belirlenmesidir. Çalışmada ise eldeki değişkenlerden kaç faktör elde edileceğinin belirlenmesinde literatürde oldukça sık kullanılan iki yönteme başvurulmuştur. Bunlardan birincisi öz değer istatistiği olarak ifade edilen ve öz değerleri 1'den büyük olan faktörlerin anlamlı olduğunu ifade eden yöntemdir. İkincisi ise Scree test olarak ifade edilen çizgi grafiğin eğiminin azaldığı yerin faktör sayını verdiğini ifade eden yöntemdir.

Faktör analizinde ölçekteki maddeler belirlenirken madde faktör yüklerinin 0.40 'tan büyük olması ve her maddenin tek bir faktörün altında toplanması gerekmektedir. Bununla birlikte her faktörün en az 3 maddeden oluşmasına dikkat edilmelidir (Otrar ve Argın, 2015: 395). Bu kapsamda ilk olarak yapılan faktör 
analizinde faktör sayısında bir kısıtlama getirilmemiş ve toplam 5 faktörün ortaya çıktığı görülmüştür. Fakat analiz sonucunda faktör yük değerleri 0,40 altında olan üç madde ( $\mathrm{M}$ 5: Üstüm (yöneticim) bana çeşitli yetki ve sorumluluklarını devreder M21: Üstüm (yöneticim) yeniliklere açıktır ve M 22: Üstüm (yöneticim) şeffaflığa önem verir) ölçekten çıkarılmıştır. Kalan 21 soruya ikinci kez faktör analizi uygulandığında binişik olan iki madde ( $M$ 23: Üstüm (yöneticim) benim iletişim bilgilerime sahiptir ve M 24: Nihai kararlar üstler (yöneticiler) tarafindan alınır) ölçekten çıkarılarak kalan 19 soruya üçüncü kez faktör analizi uygulanmıştır. Ölçekte kalan 19 soruya ilişkin öz değerleri 1'den büyük olan 4 faktörün ortaya çıtığı görülmüştür. Bu kapsamda yapılan analizler sonucunda Tablo 4 ve Şekil 1'de görülen faktör yapısı ortaya çıkmıştır.

Şekil 1. Maddelere Iliş̧kin Öz Değer-Faktör Eğilim Grafiği

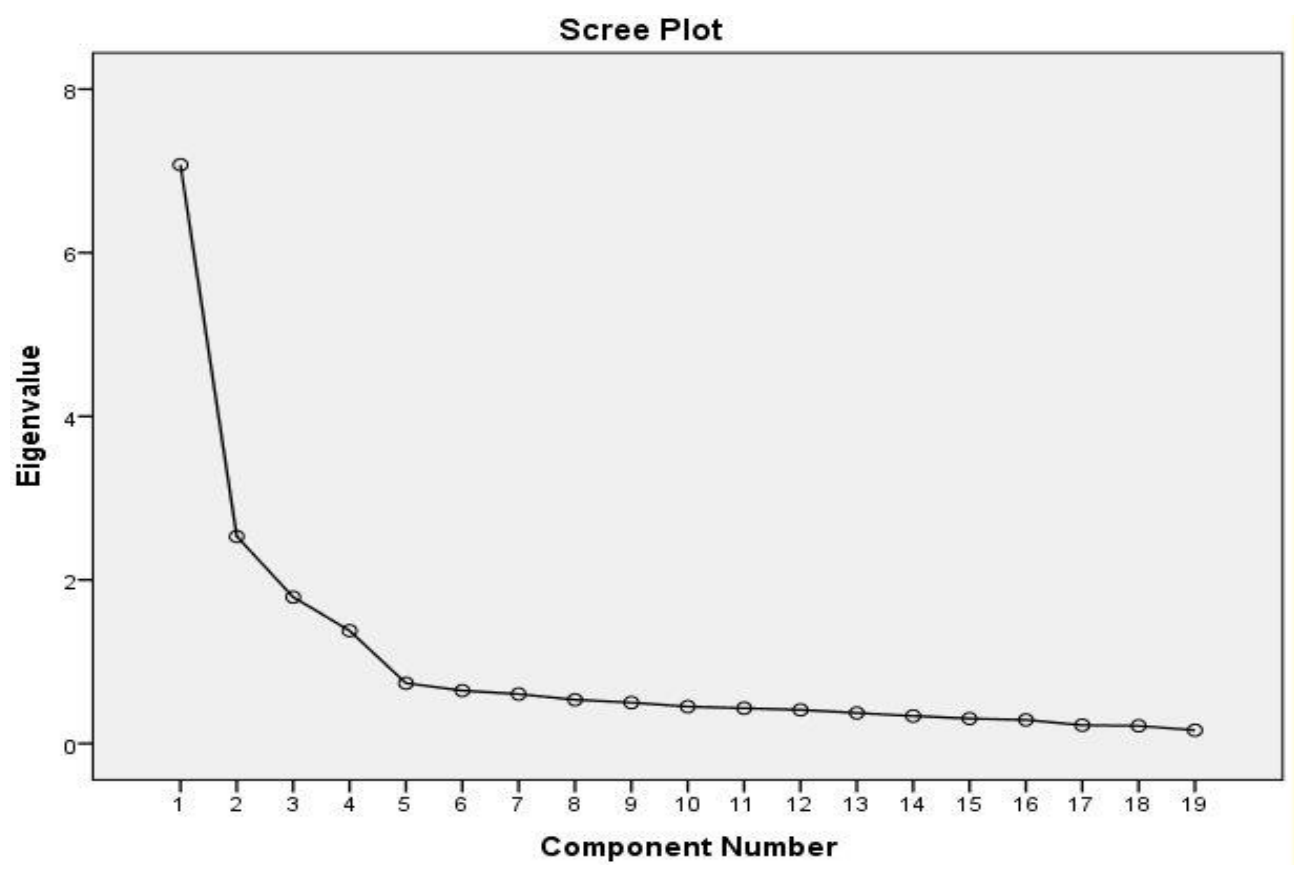

Şekil 1 madde öz değerlerinin birleştirilmesiyle elde edilen grafiği göstermektedir. Elde edilen çizgi grafiğine göre grafiğin yatay şekil aldığı noktaya kadar olan faktörler maksimum faktör sayısını vereceğinden dolayı Şekil 1'e göre faktör sayısının 4 ya da 5 faktör ile sınırlandırılabileceği söylenebilir. Çünkü 4'üncü faktörden itibaren çizgi grafiği eğimini önemli ölçüde kaybetmeye başlamıştır. Bu kapsamda Tablo 4'te öz değer istatistikleri, açıklanan varyans oranları ve faktör yapısı görülebilmektedir.

Tablo 4'te görüldüğü üzere öz değer ve varyans açıklama oranlarına bakıldığında öz değeri 1'den büyük olan dört faktörün ortaya çıktğı̆ tespit edilmiştir. Söz konusu dört faktöre ilişkin toplam açıklanan varyans oranı ise \% 67,238'dir. Birinci faktöre ilişkin açıklanan varyans miktarı \% 21,365, ikinci faktör ilişkin açıklanan varyans miktarı \% 17,599, üçüncü faktöre ilişkin açıklanan varyans miktarı \% 14,148, dördüncü faktöre ilişkin açıklanan varyans miktarı ise \% 14,125 olarak ortaya çıkmıştır. Elde edilen varyans oranlarının yüksek olması ölçeğe ilişkin faktör yapısının güçlüğünü göstermesi açısından önemlidir. Büyüköztürk (2002: 479)'e göre analizde yer alan değişkenlerin toplam varyansın 3'te 2'sini açıklaması yeterlidir. Fakat sosyal bilimler açısından bu oranın \% 40-60 aralığında olması kabul edilebilirdir (Scherer vd,1988; Tavşancıl, 2010). Bu nedenle çalışmada \% 67,238'lik açıklanma oranının yeterli olduğu söylenebilir. 
Tablo 4. Mantar Yönetim Ölçeğinin Açıklayıcı Faktör Analizi Sonuçları

\begin{tabular}{|c|c|c|c|c|}
\hline \multirow{2}{*}{ Madde } & \multicolumn{4}{|c|}{ Faktör Yük Değerleri } \\
\hline & Faktör 1 & Faktör 2 & Faktör 3 & Faktör 4 \\
\hline $\begin{array}{l}\text { Üstüm (yöneticim) kurumla ilgili stratejik bilgileri benimle } \\
\text { paylaşmaktan kaçınır. }\end{array}$ & ,759 & ,215 & ,063 & 141 \\
\hline $\begin{array}{l}\text { Üstüm (yöneticim) benimle ilgili bir karar alınacağında benimle } \\
\text { bilgi paylaşmaz. }\end{array}$ & ,740 & ,166 & 102 & 149 \\
\hline Üstüm (yöneticim) bazı bilgilerin gizli kalması gerektiğini düşünür. & ,831 & ,031 & 134 & ,054 \\
\hline Üstlerimle (yöneticilerimle) düzenli toplantılar yaparız. (R) & ,852 & 195 & 047 & ,102 \\
\hline Üstüm (yöneticim) beni her türlü konuda bilgilendirir. (R) & ,765 & 064 & 082 & ,231 \\
\hline $\begin{array}{l}\text { Üstüm (yöneticim) benimle bilgi paylaşımını zaman kaybı olarak } \\
\text { görür. }\end{array}$ & ,784 & 183 & ,046 & 105 \\
\hline $\begin{array}{l}\text { Üstüm (yöneticim) sahip olduğu bilgileri kendisi için bir güç kaynağı } \\
\text { olarak görür. }\end{array}$ & ,194 & ,764 & 190 & 190 \\
\hline Üstüm (yöneticim) bizlere karşı korku kültürü yaymaya çalışır. & ,262 & ,629 & ,217 & ,262 \\
\hline $\begin{array}{l}\text { Üstüm (yöneticim) kurumda yaptığım iş ile ilgili başarı elde } \\
\text { ettiğimde bunu takdir eder. (R) }\end{array}$ & 093 & ,725 & 172 & 166 \\
\hline $\begin{array}{l}\text { Üstüm (yöneticim) kariyerimde yükselme konusunda beni } \\
\text { destekler. (R) }\end{array}$ & 152 & ,808 & 080 & ,210 \\
\hline $\begin{array}{l}\text { Üstüm (yöneticim) kendimi geliştirmem için gerekli imkânları bana } \\
\text { sunmaktan kaçınır. }\end{array}$ & 159 & ,857 & 111 & 178 \\
\hline $\begin{array}{l}\text { Üstüme (yöneticime) işlerle ilgili gerek duyduğum her an ulaşmam } \\
\text { mümkündür. (R) }\end{array}$ & 148 & 075 & ,735 & 148 \\
\hline Üstüm (yöneticim) tek taraflı bir iletişim sürecini benimser. & 085 & 110 & ,810 & 161 \\
\hline $\begin{array}{l}\text { Üstüm (yöneticim) yaptığım işlerle ilgili benden düzenli rapor ister. } \\
\text { (R) }\end{array}$ & ,006 & 187 & ,769 & ,061 \\
\hline Üstüm (yöneticim) bana ulaşırken tek bir iletişim kanalını kullanır. & 111 & ,202 & ,777 & ,080 \\
\hline $\begin{array}{l}\text { Üstüm (yöneticim) herhangi bir karar alınacağı zaman benim } \\
\text { görüşlerimi önemsemez. }\end{array}$ & 163 & ,261 & 087 & ,802 \\
\hline $\begin{array}{l}\text { Üstler (yöneticiler) tarafından verilen talimatları (görevler) } \\
\text { sorgulamam istenmez. }\end{array}$ & 199 & 165 & 023 & ,802 \\
\hline $\begin{array}{l}\text { Üstüm (yöneticim) bana çeşitli yetki ve sorumluluklarını } \\
\text { devretmekten kaçınır. }\end{array}$ & 187 & ,200 & ,282 & ,698 \\
\hline $\begin{array}{l}\text { Üstümün (yöneticimin) katılımcı yönetim tarzının benimsendiğine } \\
\text { inanmıyorum. }\end{array}$ & 111 & ,268 & 184 & ,723 \\
\hline Öz Değerler & 7.075 & 2.530 & 1.790 & 1.379 \\
\hline Toplam Varyans (\%) & 21,365 & 17,599 & 14,148 & 14,125 \\
\hline Birikimli Varyans (\%) & 21,365 & 38,965 & 53,114 & 67,238 \\
\hline
\end{tabular}

Tablo 4'e göre maddelerin faktör yüklerine bakıldığında; ilk 7 maddeden 6'sı (M1-M2-M3-M4-M6M7) birinci faktör altında toplanıp 0,740 ile 0,852 arasında değerler almıştr. Sonraki 5 madde (M8-M12) ikinci faktör altında toplanıp 0,629 ile 0,857 arasında değerler almıştır. Daha sonraki 4 madde ise (M13-M16) üçüncü faktör altında toplanıp 0,735 ile 0,810 arasında değerler almıştr. Sonraki 4 maddenin de (M17-M20) dördüncü faktör altında toplanıp 0,698 ile 0,802 arasında değerler aldığı görülmektedir. Tüm bu analizler sonucunda ölçeğin 4 alt faktörden ve 19 sorudan oluştuğu belirlenmiştir. Bu noktada her bir madde incelenerek faktörler isimlendirilmiştir. Bu bağlamda birinci faktör bilgi paylaşımı ile ilgili problemleri yansıtan maddeleri içerdiğinden dolayı "yetersiz bilgi paylaşımı" faktörü olarak isimlendirilmiştir. İkinci faktör yöneticinin elindeki gücü kaybetme korkusunu ifade eden maddeleri içerdiğinden "güç kaybı endişesi" şeklinde ifade edilmiştir. Üçüncü faktör iletişim problemlerini ifade eden maddelerden oluşmasından dolayı 
"iletişim yetersizliği" ve son faktör ise katılımcı yönetim ile ilgili sıkıntıları içeren ifadelerden oluşmasından dolayı "katılımcı yönetim eksikliği" şeklinde isimlendirilmiştir.

\subsubsection{Doğrulayıcı Faktör Analizi (DFA)}

Ölçek geliştirme çalışmalarında AFA sonucu ortaya çıkan modelin doğrulanmasına ihtiyaç duyulmaktadır. Bu nedenle Doğrulayııı Faktör Analizi (DFA) araştırmacı(lar) tarafindan var olan bir ölçeği test etmek için kullanılmaktadır. Yani DFA yapılabilmesi mevcut bir modelin (ölçeğin) var olması gerekmektedir. Bu nedenle araştırmacı(lar) ölçekteki soruların neyi ölçtüğünü kuramsal olarak bilmelidir. Bu nedenle ölçek geliştirme çalışmalarında ilk önce AFA sonrasında farklı bir örneklem üzerinde DFA yapılması daha uygundur. Çalışmada da AFA sonucunda elde edilmiş olan faktörler yapılarının uygunluğunu test etmek amacıyla örneklemi farkıı (kamu üniversitelerinde görev yapan) 240 araştırma görevlisi üzerinde Doğrulayıcı Faktör Analizi gerçekleştirilmiştir.

DFA modelin nasıl kurulacağı ile ilgili bilgi vermemesine karşın uyum iyiliği değerleri aracılığı ile araştırmacıya uygun modelin oluşturulması konusunda yardımcı olmaktadır (Schumacker ve Lomax, 2010). Böylece bu analiz AFA ile kurulan modelde değişiklikler yaparak en uygun yapının ortaya çıkmasını sağlamaktadır. Bu kapsamda Şekil 2'de modele ilişkin DFA sonuçları görülebilmektedir.

Şekil 2. Ölçeğe illişkin Birinci Düzey Doğrulayıcı Faktör Analizi Sonuçları

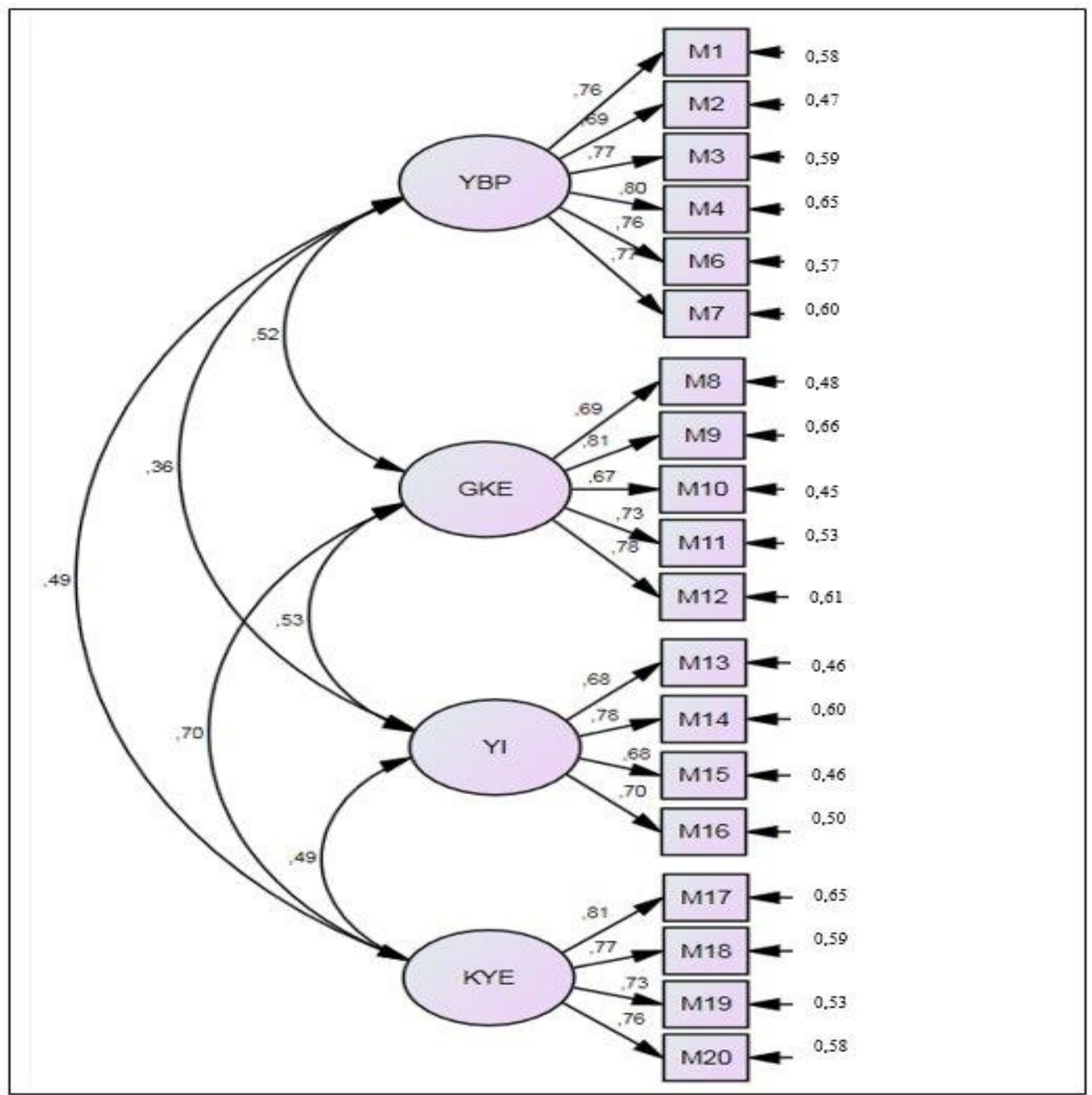

YBP: Yetersiz Bilgi Paylaşımı; GKE: Güç Kaybı Endişesi; Yi: Yetersiz Iletişim; KYE: Katııımcı Yönetim Eksikliği 
Mantar Yönetim Ölçeği için yapılan DFA sonucuna oldukça iyi uyum değerleri yakalanmış ve ölçekten çıkartılan madde olmamıştır. Şekil 2'de görüldüğü üzere DFA'ya ilişkin faktör yük değerleri "yetersiz bilgi paylaşımı" boyutunda 0,69 - 0,80; "güç kaybı endişesi" boyutunda 0,69-0,81; "yetersiz iletişim" boyutunda $0,68-0,78$ ve "katılımcı yönetim eksikliği" boyutunda $0,73-0,81$ arasındadır. Mantar Yönetim Ölçeği'nin alt boyutlarına ait hata varyanslarının ise "yetersiz bilgi paylaşımı" boyutunda 0,47 - 0,65; "güç kaybı endişesi" boyutunda 0,45-0,66; "yetersiz iletişim" boyutunda 0,46-0,60 ve "katılımcı yönetim eksikliği" boyutunda $0,53-0,65$ arasında ve kabul edilebilir düzeyde olduğu tespit edilmiştir.

Ölçeğe ilişkin uyum iyiliği değerleri incelenirken ilk olarak X²/df (Ki-Kare/Serbestlik derecesi) değerine bakmak yerinde olacaktır. Çünkü bu değer uyum yeterliliğinin test edilmesinin bir yolu olduğundan dolayı önemlidir. Bu değer normalde 0-2 arasında olmalı iken 2-5 arasında olması da kabul edilebilir. RMSEA değeri yaklaşık ortalamaların karekökü olup, bu değerin normalde 0,05 'ten küçük olması gerekli iken 0,05 ile 0,08 arası değerler de kabul edilebilirdir. RMR değeri sıfira yakınlaştıkça model daha iyi uyum iyiliği göstermektedir. Normalde bu değerin 0,05'ten küçük olması gerekmektedir. Fakat 0,05 ile 0,08 arasındaki değerler de kabul edilebilir değerlerdir. İyi uyum indeksi olarak ifade edilen GFI değeri ise modelin örneklemin kovaryans matrisini hangi miktarda ölçtüğünün bir göstergesidir (Çokluk vd, 2012). Bu değer 0 ile 1 arasında değişen değerler almaktadır. 0'dan 1'e yaklaştikça daha yüksek uyumun olduğunu göstermektedir. GFI normalde 0,95 'ten büyük olması gerekli iken 0,90'dan büyük değerler de kabul edilebilir değerlerdir. Karşılaştırmalı uyum indeksini ifade eden CFI değeri ise değişkenler arasında ilişki olmadığını savunan modeldir (Çokluk vd., 2012). Bu değerin ise 0,97' den büyük olması beklenir iken 0,95'ten büyük değerler de kabul edilebilir olarak ifade edilir. AGFI indeksi GFI'nın yüksek örnek hacminden kaynaklı eksikliğini ortadan kaldırmak için kullanılmaktadır. Yani düzenlenmiş iyi uyum indeksini ifade etmektedir. AGFI değeri 0 ile 1 arasında da değişen değerler alır. Bununla birlikte AGFI değerinin 0,90 ve üzeri değerler alamsı beklenirken 0,85 ve üzeri değerler de kabul edilebilir değerlerdir. NFI ise normlaştrılmış uyum indeksi anlamına gelir. NFI değerinin 0,95 'ten yüksek olması beklenir fakat 0,90' dan büyük değerlerde kabul edilebilirdir. Bir başka uyum indeks değeri olan RFI'nın da 0,90 ve üzeri değerler alamsı beklenirken 0,85 ve üzeri değerler de kabul edilebilirdir. Tüm bu açıklamalar ışığında Tablo 5 'te ise normal ve kabul edilebilir uyum iyiliği değerleri ile birlikte çalışmada elde edilen uyum iyiliği değerleri özetlenmiştir.

Tablo 5. Birinci Düzey DFA Standart ve Çalışmaya Iliş̧kin Uyum Ölçütleri

\begin{tabular}{cccc}
\hline Uyum Ölçütleri & Normal Ölçüt & Kabul Edilebilir Ölçüt & Elde Edilen Uyum Ölçütleri \\
$\mathbf{X}^{2} / \mathbf{d f}$ & $\leq 2$ & $\leq 3$ & 1,66 \\
RMSEA & $\leq 0,05$ & $\leq 0,08$ & 0,05 \\
RMR & $\leq 0,05$ & $\leq 0,08$ & 0,04 \\
GFI & $\geq 0,95$ & $\geq 0,90$ & 0,908 \\
CFI & $\geq 0,97$ & $\geq 0,95$ & 0,955 \\
NFI & $\geq 0,95$ & $\geq 0,90$ & 0,899 \\
RFI & $\geq 0,90$ & $\geq 0,85$ & 0,879 \\
AGFI & $\geq 0,90$ & $\geq 0,85$ & 0,880 \\
\hline
\end{tabular}

Kaynak: Schermelleh, vd., 2003'den uyarlanmıştır.

Tablo 5 incelendiğinde $X^{2} / d f$ değeri 1,66 bulunmuş olup mükemmel uyumu işaret etmektedir. RMSEA değerine bakıldığında 0,05 çıkmıştır. Bu değerin de mükemmel uyuma işaret ettiği söylenebilir. Ölçeğe ilişkin RMR değeri de 0,04 olup mükemmel uyumu göstermektedir. Ölçeğin GFI değeri 0,90 ile CFI değeri ise 0,95 çıkmıştır. 0 ile 1 arasında değer alan bu ölçütlerden hem GFI hem de CFI değeri mükemmel uyumu göstermektedir. Ayrıca AGFI, NFI ve RFI değerleri sırasıyla $0,88-0,89$ ve 0,87 çıkmış olup kabul edilebilir uyumu işaret etmektedirler.

Mantar Yönetim Ölçeği için yapılmış olan birinci düzey DFA sonuçlarının iyi uyum değerleri elde edilmesinin sonrasında ölçekte yer alan boyutların mantar yönetimi örtük değişkeninin birer bileşeni olup olmadığını belirlemek için ikinci düzey DFA yapılmıştır. Bu bağlamda yapılan ikinci düzey DFA sonuçları Şekil 3'te görülmektedir. 
Şekil 3. Ölçeğe illişkin İkinci Düzey Doğrulayıcı Faktör Analizi Sonuçları

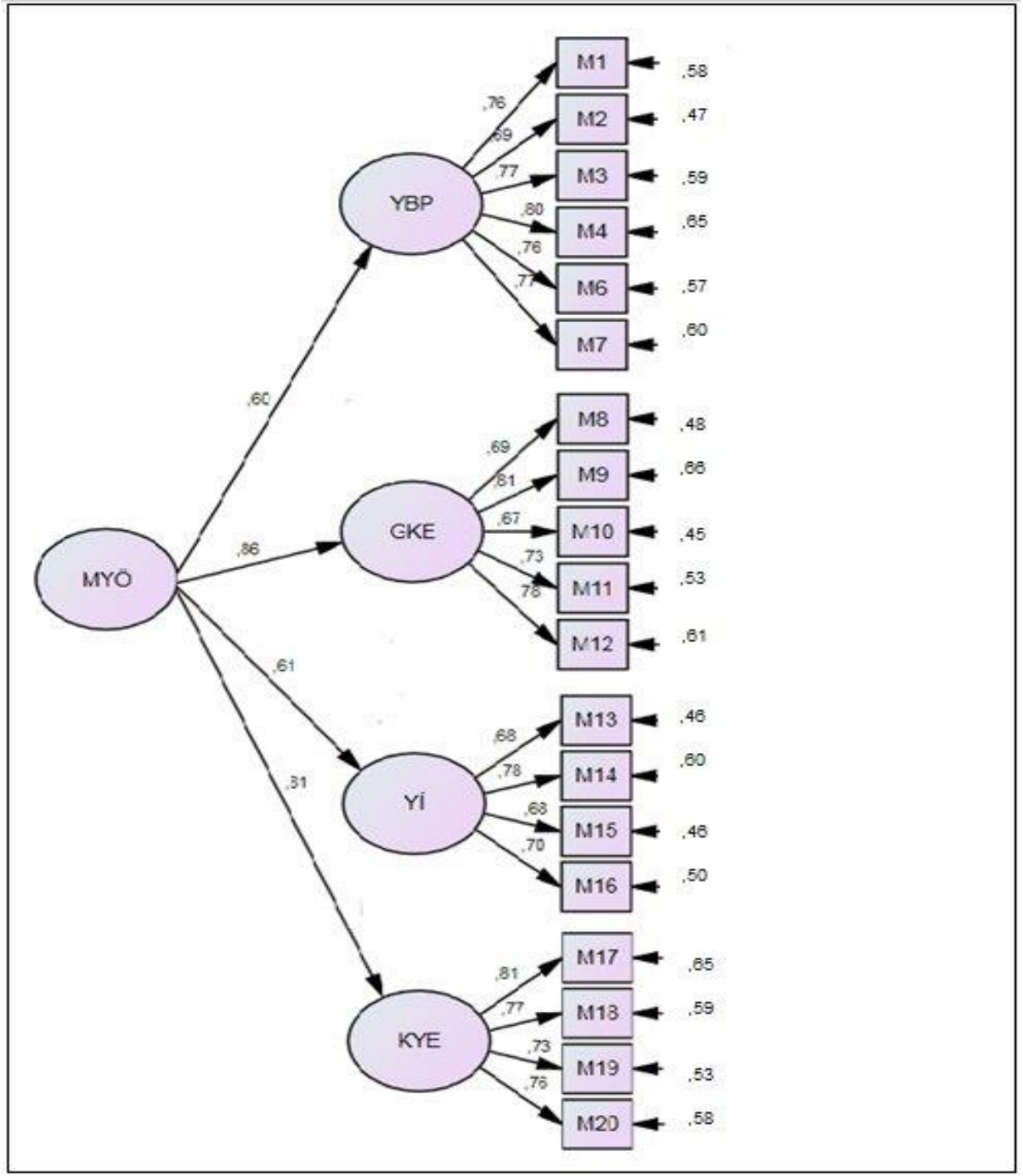

YBP: Yetersiz Bilgi Paylaşımı; GKE: Güç Kaybı Endişesi; Yi: Yetersiz iletişim; KYE: Katılımcı Yönetim Eksikliği; MYÖ: Mantar Yönetim Ölçeği

Tablo 6. İkinci Düzey DFA Standart ve Çalışmaya İlişkin Uyum Ölçütleri

\begin{tabular}{cccc}
\hline Uyum Ölçütleri & Normal Ölçüt & Kabul Edilebilir Ölçüt & Elde Edilen Uyum Ölçütleri \\
$\mathbf{X}^{2} /$ df & $\leq 2$ & $\leq 3$ & 1,64 \\
RMSEA & $\leq 0,05$ & $\leq 0,08$ & 0,05 \\
RMR & $\leq 0,05$ & $\leq 0,08$ & 0,04 \\
GFI & $\geq 0,95$ & $\geq 0,90$ & 0,908 \\
CFI & $\geq 0,97$ & $\geq 0,95$ & 0,956 \\
NFI & $\geq 0,95$ & $\geq 0,90$ & 0,899 \\
RFI & $\geq 0,90$ & $\geq 0,85$ & 0,880 \\
AGFI & $\geq 0,90$ & $\geq 0,85$ & 0,881 \\
\hline
\end{tabular}

Kaynak: Schermelleh, vd., 2003'den uyarlanmıştır. 
İkinci düzey DFA sonuçları incelendiğinde öncelikle ölçeği oluşturan faktörlerin mantar yönetimini pozitif ve anlamlı bir şekilde etkilediği sonucuna varılmıştır. Mantar yönetimini en yüksek düzeyde "GKE" faktörünün etkilediği görülmektedir $(r=0,86 ; p<0,01)$. Bu faktörü sırasıyla "KYE" $(r=0,81 ; p<0,01)$, "Yi" ( $r=$ $0,61 ; p<0,01)$, "YBP" $(r=0,60 ; p<0,01)$ faktörleri takip etmektedir. İkinci düzey faktör analizi sonucu hesaplanan uyum iyiliği değerlerine bakıldığında $X^{2} / d f$ değeri 1,64 bulunmuştur. Diğer uyum iyiliği değerleri olan RMSEA 0,05; RMR 0,04; GFI 0,90; CFI 0,95; NFI 0,89; RFI 0,88 ve AGFI 0,88 bulunmuş olup ikinci düzey faktör analizi için tüm uyum iyiliği değerlerinin mükemmel ve iyi uyum değerini yakalamışlardır. İkinci düzey DFA sonuçlarının özeti standart değerlerle karşılaştrılmalı bir şekilde Tablo 6'da görülebilmektedir.

\section{4. Ölçeğin Güvenilirliği}

Ölçeğin güvenirlik çalışması yapılırken Cronbach Alpha İç Tutarlııı Katsayısı ve Test Tekrar Test değerlerine bakılmıştır. Ölçeğin güvenirlik düzeyini belirlemek için yapılan Cronbach Alpha iç tutarlılık katsayısı Cronbach (1951) tarafindan geliştirilen ve kendi adını taşıyan $\alpha$ katsayısına bakılarak Likert tipi ölçeklerin güvenilirliği kestirilmeye çalışmaktadır. Alfa $(\alpha)$ katsayısına bakılarak ölçeğin güvenilirliği (Kayış, 2010: 405);

- $0,00 \leq \alpha<0,40$ ölçek güvenilir değil,

- $0,40 \leq \alpha<0,60$ ölçeğin güvenilirliği düşük,

- $0,60 \leq \alpha<0,80$ ölçek oldukça güvenilir,

- $0,80 \leq \alpha<1,00$ ölçek yüksek derecede güvenilir şeklinde yorumlanabilir.

Çalışmada da hem ölçeğin geneline hem de alt faktörlere ilişkin bir $(\alpha)$ katsayısı hesaplanmıştrr. Ayrıca ölçekteki faktörler arasındaki ilişkiler de incelenmiştir. Bu kapsamda ortaya çıkan sonuçlar Tablo 7'de özetlenmiştir.

Tablo 7. Mantar Yönetim Ölçeği'ni Oluşturan Faktörler Arası Illişkiler ve Cronbach Alpha Değerleri

\begin{tabular}{|c|c|c|c|c|c|c|c|}
\hline & Ort. & SS & & 1 & 2 & 3 & 4 \\
\hline Mantar Yönetim Ölçeği & 3,87 & ,5680 & $(0,903)$ & & & & \\
\hline 1- Yetersiz Bilgi Paylaşımı & 4,15 & ,7106 & & $(0,899)$ & & & \\
\hline 2- Güç Kaybı Endişesi & 3,66 & ,7338 & & $0,419^{* *}$ & $(0,879)$ & & \\
\hline 3- İletişim Yetersizliği & 4,01 & ,7360 & & $0,252^{* *}$ & $0,402^{* *}$ & $(0,814)$ & \\
\hline 4- Katılımcı Yönetim & 3,68 & ,7668 & & $0,407^{* *}$ & $0,552^{* *}$ & $0,371^{* *}$ & $(0,836)$ \\
\hline
\end{tabular}

Tablo 7'ye göre Mantar Yönetim Ölçeği'ni oluşturan faktörler birbirleriyle pozitif ve anlamlı ilişki içerisindedir. Ayrıca Mantar Yönetim Ölçeği'ne ilişkin $(\alpha)$ katsayısı "yetersiz bilgi paylaşımı" faktöründe 0,899, "güç kaybı endişesi" faktöründe 0,879, "iletişim yetersizliği" faktöründe 0,814 ve "profesyonel yönetim eksikliği" faktöründe 0,836 olarak bulunmuştur. Ölçeğin genel güvenirlik katsayısının ise 0,903 olduğu tespit edilmiştir. Bu kapsamda ölçeğin iç tutarlılığı hem ölçek geneli için hem de alt faktörler açısından yüksek derecede güvenilir çıkmıştır.

Ayrıca ölçüm aracının farklı zamanlarda tutarlı sonuç vermesi ve zaman göre değişmezlik gösterip göstermediğini yani kararlılığını tespiti için test tekrara test korelasyonu hesaplanmıştır (Gözüm ve Aksayan, 2003). Tavşancıl (2010)'a göre iki test arasındaki süre 2-3 ile 4-6 hafta arasında değişiklik gösterebilmektedir. Çalışmada da örneklemde yer almayan (35. ve 39. madde ile kamu üniversitesinde görevlendirilmiş) 30 adet araştırma görevlisinin test tekrar test analizi için iki hafta ara ile ölçeği tekrar cevaplandırması sağlanmıştır. Her iki uygulamadan elde edilen puanların Korelasyon Katsayısı 0,823 $(p<0,000)$ olarak bulunmuştur (Tablo 8). Buna göre her iki uygulama arasında yüksek düzeyde anlamlı bir ilişki söz konusudur. Bu durumda ölçeğin ölçüm yeteneği zaman göre değişiklik göstermemektedir. 
Mantar Yönetim Ölçeği Geliştirilmesi Üzerine Bir Çalışma

Tablo 8. Mantar Yönetim Ölçeği'nin Test-Tekrar Test Puanlarına ilişkin Korelasyon Analizi Sonuçları

\begin{tabular}{lccc}
\hline Mantar Yönetim Ölçeği & Sayı (N) & $\mathbf{r}$ & $\mathbf{p}$ \\
ilk Uygulama & 30 & 0,823 & 0,000 \\
\cline { 2 - 4 }
\end{tabular}

Bu bağlamda "yetersiz bilgi paylaşımı", "güç kaybı endişesi", "yetersiz iletişim" ve "katlımcı yönetim eksikliği" boyutlarının mantar yönetimi denilen yapıyı anlamlı şekilde açıkladığı söylenebilir. Tüm bu ortaya çıkan bulgular çerçevesinde mantar yönetim ölçeğin geçerliğinin ve güvenirliğinin sağlandığını söylemek yanlış olmayacaktır.

\section{Sonuç ve Öneriler}

Mantar yönetimi yöneticilerin mantar yetiştiriciliğinde olduğu gibi çalışanı karanlıkta bırakıp ona sadece intiyacı olan kaynakları sağlayarak performansının artırılabileceğini ifade eden bir metafordur. Temelinde yöneticinin çalışanına karşı sınırlı bilgi paylaşımında bulunduğu ve karar verme noktasında çalışanı işin içerisine katmayan bir yönetim tarzını ifade etmektedir. Böyle düşünen yöneticiler çalışanları ile çok fazla iletişime geçme isteğinde olmamakta sadece gerekli alet edevatın çalışana sağlanmasının yeterli olduğunu düşünmektedirler. Ayrıca bu durumun arakasında çalışanın ne istediğinden ziyade kurum performansının önemli olduğunu düşüncesi yatmaktadır. Kazan-kazan felsefesinin önemli olduğu günümüz iletişim çağında ise bu durumun mantar yetiştiriciliğindeki gibi gerçekten performansı artırıp artırmayacağı ise merak edilen bir husustur. Bununla birlikte "mantar yöneticiliği diğer örgütsel davranış konuları ile bağlantılı mıdır?" sorusu da akla gelmektedir. Bu noktada mantar yönetim tarzının etkilerinin ve çalışanların mantar yönetim algısının ölçülebilmesi için bir Mantar Yönetim Ölçeği geliştirilmesinin örgütsel davranış literatürü açısından önem taşıdığı düşünülmüştür.

Bu bağlamda çalışmada hem özel hem de kamu üniversitelerinde görev yapan araştırma görevlilerinin mantar yönetim algılarını belirlemeye yönelik olarak bir ölçek geliştirilmesi amaçlanmıştır. Bu amaç doğrultusunda ilk olarak ölçek için bir madde havuzu oluşturularak uzman görüşleri alınmıştır. Bu noktada soruların kapsam geçerliğinin değerlendirilmesi için 10 uzmanın görüşü alınmıştır. Ardından Lawshe tekniği kullanılarak maddelerin KGO'ları hesaplanmıştır. Bu aşamada 1 madde ölçek dışında bırakılmıştır. Ardından ölçeğin faktör yapısını belirlenmek amacıyla AFA, yapı geçerliğini belirlenmek amacıyla ise birinci ve ikinci düzey DFA yapılmıştır. Kapsam geçerliği sonrası geriye kalan 23 maddelik ölçüm aracı AFA için özel üniversitede çalışan 216, DFA için ise kamu üniversitesinde çalışan 240 araştırma görevlisine uygulanmıştir. Yapılan AFA sonucunda ölçeğin 19 madde ve 4 faktörden oluştuğu görülmüştür. Bu faktörler "yetersiz bilgi paylaşımı", "güç kaybı endişesi", "yetersiz iletişim" ve "katılımcı yönetim eksikliği” olarak isimlendirilmiştir. Ölçekte yer alan 19 maddeye ilişkin faktör yüklerinin Varimax rotasyon sonucunda 0,629 ile 0,857 arasında değiştiği görülmektedir. Söz konusu 4 faktörün açıkladığı toplam varyans oranını ise \% 67,23 olmuştur.

Ölçeğin yapı geçerliğini test etmek amacıyla birinci ve ikinci düzey DFA yapılmıştır. Birinci düzey DFA sonucunda $\mathrm{X}^{2}$ /df değeri 1,66; GFI değeri 0,908; CFI değeri 0,955; RMSEA değeri 0,05 bulunmuştur. Bu sonuçlar modelin iyi uyum değerlerine sahip olduğunu göstermektedir. Bu aşamanın sonrasında ölçeğin mantar yönetimi olarak adlandırılan genel yapıyı ortaya koyup koymadığını göstermek için yapılan ikinci düzey faktör analizi sonucunda uyum iyiliği değerlerinin $\left(\mathrm{X}^{2} / \mathrm{df}=1,64 ; \mathrm{GFI}=, 908 ; \mathrm{CFI}=, 956 ; \mathrm{RMSEA}=0,05\right)$ yeterli düzeyde olduğu görülmüştür. Bu sonuçlar ölçeğin yapı geçerliğine sahip olduğunu göstermesi açısından önemlidir. Hem AFA hem de DFA analizleri sonucu elde edilen veriler ölçeğin hem kapsam hem de yapı geçerliğinin yüksek olduğunu göstermektedir.

Bu analizlerle birlikte ölçeğin güvenirliği için iç tutarlılık ve test tekrar test katsayıları incelenmiştir. Bu kapsamda yapılan analizler sonucunda ölçeğin tamamı için Cronbach Alpha değeri 0,90 ve "yetersiz bilgi paylaşımı"; "güç kaybı endişesi"; "yetersiz iletişim" ve "katılımc yönetim eksikliği" boyutlarında sırasıyla 0,89; 0,$87 ; 0,81$ ve 0,83 olarak hesaplanmıştır. Ölçeğin tamamına ilişkin ve alt boyutlarına ilişkin $\alpha$ değerlerinin 0,70 üzerinde çıkması ölçeğin tümünün ve alt boyutlarında yer alan maddelerin kendi içerisinde tutarı olduklarını ifade etmektedir. Zamana göre ölçeğin kararlığını belirlemek için yapılan test tekrar test sonucuna göre ise 
korelasyon katsayısı ( $r=0,82 ; p<0,05$ manidar bulunmuştur. Bu kapsamda yapılan güvenirlik ve geçerlik analizleri sonucunda 4 faktörlü ve 19 maddeden oluşan Mantar Yönetim Ölçeği 5'li Likert tipinde hazırlanmıştır. Bu nedenle ölçekten elde edilebilecek en yüksek puan 95, en düşük puan ise 19 'dur. Ölçek geliştirme literatürünün bütün ilkeleri dikkate alınarak geliştirilen bu ölçek yöneticilerin mantar yönetim düzeylerinin belirlenmesinde ve çalışanların yöneticiye ilişkin mantar yönetim düzeyi algılarının ölçümlenmesinde kullanılabilir.

Çalışma hem kamu hem de özel sektörü ele alarak yapılmıştır. Örneklemde araştırma görevlileri (akademisyenler) yer aldığından dolayı eğitim düzeyi oldukça yüksektir. Bu durumda elde edilen bulgu ve sonuçların genellemesinde sınırlılık söz konusu olabilir. Mantar yönetim anlayışı ve yönetimde sınırlılık içerdiğinden eğitim kuruluşlarında uygulanması performansı düşürebilir. Fakat mekanik örgüt yapısının gerekli olduğu ve kaosu önlemek, mahremiyetin korunması gerektiği durumlarda kullanışı bir araç haline dönüşebilir (Kılıç ve Olgun, 2017). Bu nedenle ölçeğin idari görevde çalışanlara uygulanması ya da farkı yapıdaki örgütlerde uygulanması durumda sonuçlar farklılaşabilir. Bu sınırlılıklar dikkate alındığında başta idari personel olmak üzere farklı sektörler üzerinde çalışmalar yapılarak ölçeğin geçerlik ve güvenirliği test edilebilir. Ayrıca ölçekten mantar yönetim tarzının diğer örgütsel davranış konuları ile ilişkisini ortaya koyan çalışmalarda da yararlanılabilir.

\section{Kaynaklar}

Büyüköztürk, Ş. (2010). Sosyal bilimler için veri analizi el kitabı. 11. Baskı, Ankara: Pegem Akademi.

Child, D. (2006). The essentials of factor analysis. 3rd Edition, London: Continuum.

Çam, O. M., \& Arabacı-Baysan, L. (2010). Tutum ölçeği hazırlamada nitel ve nicel adımlar. Hemşirelikte Araştırma Geliştirme Dergisi, 2, 59-71.

Çokluk, Ö., Şekercioğlu, G., \& Büyüköztürk, Ş. (2012). Sosyal bilimler için çok değişkenli istatistik: SPSS ve LISREL uygulamaları. Ankara: Pegem Akademi.

Davis, L. L. (1992). Instrument review: Getting the most from a panel of experts. Applied Nursing Research, 5, 194-197.

Dunteman, G.H. (1989). Principal components analysis. London: Sage Publication.

Field, A. (2005). Discovering statistics using SPSS. 2nd Edition, London: Sage Publication.

Floyd, F. J., \& Widaman, K. F. (1995). Factor analysis in the development and refinement of clinical assessment Instruments. Psychological Assessment, 7(3), 286-299.

Geckoboard \& Censuswide (2015). Mushroom management: Leaves employees heading for the door. www.geckomoard.com, (01.05.2017).

Gözüm, S., \& Aksayan, S. (2003). Kültürlerarası ölçek uyarlaması için rehber II: Psikometrik özellikler ve kültürlerarası karşılaştırma. Hemşirelik Araştirma Dergisi, 1(5), 3-14.

Jeong, J. (2004). Analysis of the factors and the roles of HRD in organizational learning styles as identified by key informants at selected corporations in The Republic of Korea. Unpublished Doctorate Dissertation, Texas.

Kayış, A. (2010). Güvenirlik analizi. (Ed.) Ş. Kalaycı, SPSS Uygulamalı çok Değiş̧kenli istatistik Teknikleri. 5. Baskı, Ankara: Asil Yayın Dağıtım.

Kılıç, T. (2015). Mushroom management theory; Sample of health sector. Academy of Strategic Management Journal, 14 (Special Issue), 83-89.

Lawshe, C. H. (1975). A Quantitative approach content validity. Personnel Psychology, 28, 563-575.

Mar, A. (2011). Mushroom management simplicable business guide. www.management.simplicable), 01.06.2017).

Otrar, M., \& Argın, F. (2015). Öğrencilerin sosyal medyaya ilişkin tutumlarını belirlemeye yönelik bir ölçek geliştirme çalışması. Eğitim ve Öğretim Araştırmaları Dergisi, 4(1), 391-403.

Özcan, K., \& Balyer, A. (2013). Liderlik oryantasyon ölçeğinin Türkçeye uyarlanması. Mersin Üniversitesi Eğitim Fakültesi Dergisi, 9(1), 136-150.

Scherer, R. F., Wiebe, F. A, Luther, D. C., \& Adams, J. S. (1988). Dimensionality of coping: Factor stability using the ways of coping questionnaire. Psychological Reports, 62(3), 763-770. 
Schermelleh-Engel, K., Moosbrugger, H., \& Müler, H. (2003). Evaluating the fit of structural equation models: Tests of signifcance and descriptive goodness - of - fit measures. Methods of Psychological Research Online, 8(2), 23-74.

Schumacker, R.E., \& Lomax, R.G. (2010). A Beginner's guide to structural equation modeling. New York: Taylor \& Francis Group.

Şencan, H. (2005). Sosyal ve davranışsal ölçümlerde güvenirlik ve geçerlik. 1. Baskı, Ankara: Seçkin Yayıncılık.

Sharma, S. (1996). Applied multivariate techniques. New York: John Wiley \& Sons Inc..

Tabachnick, B. G., \& Fidell, L. S. (2001). Using multivariate statistics. 4th Edition, Boston: Allyn and Bacon.

Tavşancıl, E. (2010). Tutumların ölçülmesi ve SPSS ile veri analizi. Ankara: Nobel Yayınevi.

Tekin, E., \& Birincioğlu, N. (2017). Bilgi çağının odak noktası üniversitelerde mantar yönetimi. International Journal of Academic Value Studies, 3(14), 22-29.

Veneziano, L., \& Hooper, J. (1997). A method for quantifying content validity of health-related questionnaires. American Journal of Health Behavior, 21(1), 67-70. 


\section{Ekler}

\section{Ek1. Mantar Yönetimi Ölçeği}

\begin{tabular}{|c|c|c|c|c|c|}
\hline Boyutlar ve ifadeler & 1 & 2 & 3 & 4 & 5 \\
\hline Yetersiz Bilgi Paylaşımı & & & & & \\
\hline Üstüm (yöneticim) kurumla ilgili stratejik bilgileri benimle paylaşmaktan kaçınır. & & & & & \\
\hline Üstüm (yöneticim) benimle ilgili bir karar alınacağında benimle bilgi paylaşmaz. & & & & & \\
\hline Üstüm (yöneticim) bazı bilgilerin gizli kalması gerektiğini düşünür. & & & & & \\
\hline Üstlerimle (yöneticilerimle) düzenli toplantılar yaparız. (R) & & & & & \\
\hline Üstüm (yöneticim) beni her türlü konuda bilgilendirir. (R) & & & & & \\
\hline Üstüm (yöneticim) benimle bilgi paylaşımını zaman kaybı olarak görür. & & & & & \\
\hline Güç Kaybı Endişesi & & & & & \\
\hline Üstüm (yöneticim) sahip olduğu bilgileri kendisi için bir güç kaynağı olarak görür. & & & & & \\
\hline Üstüm (yöneticim) bizlere karşı korku kültürü yaymaya çalışır. & & & & & \\
\hline Üstüm (yöneticim) kurumda yaptığım iş ile ilgili başarı elde ettiğimde bunu takdir & & & & & \\
\hline Üstüm (yöneticim) kariyerimde yükselme konusunda beni destekler. (R) & & & & & \\
\hline Üstüm (yöneticim) kendimi geliştirmem için gerekli imkânları bana sunmaktan ka & & & & & \\
\hline Yetersiz İletişim & & & & & \\
\hline Üstüme (yöneticime) işlerle ilgili gerek duyduğum her an ulaşmam mümkündür. & & & & & \\
\hline Üstüm (yöneticim) tek taraflı bir iletişim sürecini benimser. & & & & & \\
\hline Üstüm (yöneticim) yaptığım işlerle ilgili benden düzenli rapor ister. (R) & & & & & \\
\hline Üstüm (yöneticim) bana ulaşırken tek bir iletişim kanalını (telefon, mail, ebys vb.) & & & & & \\
\hline Katııımcı Yönetim Eksikliği & & & & & \\
\hline Üstüm (yöneticim) herhangi bir karar alınacağı zaman benim görüşlerimi önemse & & & & & \\
\hline Üstler (yöneticiler) tarafından verilen talimatları (görevler) sorgulamam istenmez & & & & & \\
\hline Üstüm (yöneticim) bana çeşitli yetki ve sorumluluklarını devretmekten kaçınır. & & & & & \\
\hline Üstümün (yöneticimin) katılımcı yönetim tarzının benimsendiğine inanmıyorum. & & & & & \\
\hline
\end{tabular}

Not: Ölçek 5'li Likert tipine göre hazırlanmıştır. Cevapların puanlaması; 1: Hiç Katılmıyorum, 2: Katılmıyorum, 3: Kısmen Katılıyorum, 4: Katılıyorum ve 5: Tamamen Katılıyorum şeklindedir. (R) ile gösterilen ifadeler ters ifadelerdir. Bu ifadeler değerlendirilirken puanlar $1=5,2=4,3=32,4=2$ ve $5=1$ şeklinde tersine çevrilmelidir. Bu durumda ölçeğin alabileceği puanların en düşüğü 19 iken en yükseği 95'tir. Ölçeğe ilişkin puanlar arttıkça mantar yönetim algısı artmaktadır. 
This Page Intentionally Left Blank 